\title{
Secretion and Expression of Matrix Metalloproteinase-2 and 9 from Bone Marrow Mononuclear Cells in Myelodysplastic Syndrome and Acute Myeloid Leukemia
}

\author{
Ajay K Chaudhary ${ }^{1 *}$, Shruti Chaudhary ${ }^{2}$, Kanjaksha Ghosh ${ }^{1}$, Chandrakala \\ Shanmukaiah ${ }^{3}$, Anita H Nadkarni ${ }^{1 *}$
}

\begin{abstract}
Background: Matrix metalloproteinase -2 (gelatinase-A, Mr 72,000 type IV collagenase, MMP-2) and -9 (gelatinase-B, Mr 92,000 type IV collagenase, MMP-9) are key molecules that play roles in tumor growth, invasion, tissue remodeling, metastasis and stem-cell regulation by digesting extracellular matrix barriers. MMP-2 and -9 are well known to impact on solid cancer susceptibility, whereas, in hematological malignancies, a paucity of data is available to resolve the function of these regulatory molecules in bone marrow mononuclear cells (BM-MNCs) and stromal cells of myelodysplastic syndrome (MDS) and acute myeloid leukemia (AML). Objectives: The present study aimed to investigate mRNA expression and gelatinase $A$ and $B$ secretion from BM-MNCs in vitro and genotypic associations of MMP-2 (-1306 C/T; rs243865), MMP-9 (-1562 C/T; rs3918242), tissue inhibitor of metalloproteinase -1 (TIMP-1) (372T/C; rs4898, Exon 5) and TIMP-2 (-418G/C; rs8179090) in MDS and AML. Results: The study covered cases of confirmed MDS $(n=50)$, AML $(n=32)$ and healthy controls $(n=110)$. MMP9 mRNA expression revealed 2 fold increased expression in MDS-RAEB II and 2.5 fold in AML M-4 (60-70\% blasts). Secretion of gelatinase- B also revealed the MMP-9 mRNA expression and ELISA data also supported these data. We noted that those patients having more blast crises presented with more secretion of MMP-9 and its mRNA expression. In contrast MMP-9 (-1562 C/T) showed significant polymorphic associations in MDS $(p<0.02)$ and AML $(p<0.02)$. MMP-9 mRNA expression of $C / T$ and $T / T$ genotypes were 1.5 and 2.5 fold increased in MDS and AML respectively. In AML, MMP-2 C/T and T/T genotypes showed 2.0 fold mRNA expression. Only MMP-9 (-1306 C/T) showed significant 4 fold $(p<0.001)$ increased risk with chemical and $x$-ray exposed MDS, while tobacco and cigarette smokers have 3 fold $(p<0.04)$ risk in AML. Conclusions: In view of our results, MMP-9 revealed synergistic secretion and expression in blast crises of MDS and AML with 'gene' polymorphic effects and is significantly associated with increased risk with tobacco, cigarette and environmental exposure. Release and secretion of these enzymes may influence hematopoietic cell behavior and may be important in the clinical point of view. It may offer valuable tools for diagnosis and prognosis, as well as possible targets for the treatments.
\end{abstract}

Keywords: MMP-2 and 9 polymorphisms - mRNA expression - myelodysplastic syndrome - acute myeloid leukemia

Asian Pac J Cancer Prev, 17 (3), 1519-1529

\section{Introduction}

Leukemia is uncontrolled proliferation of hematopoietic stem cells that do not retain the capacity to differentiate normal to mature blood cells (Sawyers et al., 1991). Myelodysplastic syndrome (MDS) is one of the preleukemic stages, which is characterized as a clonal hematopoietic disorder with defective proliferation, differentiation and apoptosis. It is associated with chromosomal aberrations (-5/del (5q),-7/del (7q), del (11q), del (12p)/ (12q),-y and +8) and differentiation (de Souza Fernandez et al., 2000), which results in a high rate of blast formation and bone marrow failure (Issa, 2013) and mostly reported in the older adults (Klepin et al., 2014).

It was observed that the MDS patients from India were much younger (Vundinti et al., 2009; Chaubey et al., 2011) than those reported from the west world (Rollison et al., 2008). The response to the treatment in these patients was poorer than those of the western world (Dakshinamurthy et al., 2005). Treatment of older adults with MDS or acute myeloid leukemia (AML) is challenging because of disease morbidity and associated treatments in Indian population. The process of leukemia transformation, 
which mostly leads from MDS to AML, is very complex and heterogeneous. Many factors are responsible to develop MDS in relatively younger population, such as abnormal mRNA gene expression, polymorphic and genetic mutations, chromosomal aberrations, deregulation of various cellular signaling pathways.

The AML is also characterized by an excessive egress of leukemic cells from bone marrow into peripheral blood, followed by an infiltration of different organs (Liver, spleen skin, or mucous membranes). The movement of leukemic cells, which are normally restricted to functional mature leukocytes, requires the cells to cross the matrix barriers and penetrate blood vessel walls, which depends on the modification and brake down of extra cellular matrix (ECM) and basement membranes (Westermarck and Kahari, 1999). Matrix metalloproteinase (MMPs) are known to be associate with cancer-cell invasion and metastasis (Egeblad and Werb, 2002) and involved in the basement-membrane penetration during metastasis (Kalluri, 2003).The MMP extensively participate in pathophysiological processes in cancer through uncontrolled modification of cancer cell growth, activation of malignant cells and, modulation of immune functions in solid and hematological malignancies (Chaudhary et al., 2013). Many clinical studies have strongly support the participation of MMPs in the invasion, metastasis and, progression of different types of human cancer (Chaudhary et al., 2010b; Chaudhary et al., 2011; Langers et al., 2012; S et al., 2013; Yang et al., 2013; Zhang et al., 2013; Gao et al., 2014; Hwang et al., 2014; Roy et al., 2014).The MMPs are regulated by the specific tissue inhibitors (TIMPs). The balance between MMPs and TIMPs is respon $\neg$ sible for physiological tissue turnover and excess protease activity. It may lead to tissue destruction and uncontrolled production of connective tissue elements. MMPs and TIMPs may play an important role in intercellular crosslink in hematopoiesis during long term mononuclear culture (LTMC) (Marquez-Curtis et al., 2001). The MMP-2 and MMP-9 are detected in myeloid cells and megakaryocytes along with MMP-2 in erythroblasts (Ogawa et al., 2000). Studies have shown the activity and participation of MMPs/TIMPs in growth and progression of lymphoid neoplasia (Stetler-Stevenson et al., 1997; Kossakowska et al., 1999; Galm et al., 2005; RedondoMunoz et al., 2010; Ishihara et al., 2012). Due to the complexity of leukemia bone marrow associated MMPs functions and its complex cellular composition, no data exist about MMP expression associated its genotypes in bone marrow mononuclear (BM-MN) hematopoietic cells.

In contrast, inclusive investigation of gelatinases-A and B (MMP-2 and MMP-9) and its tissue inhibitors (TIMP1 and TIMP-2) mRNA expression and polymorphic association in myelodysplastic syndrome (MDS) and acute myeloid leukemia (AML) cells of the leukemia system and their prognostic significance in hematological malignancies has not been carried out. In our study, we have tried to explore the genetic alterations and mRNA regulatory dysfunctions of MMPs (MMP-2 \& -9) and TIMPs (TIMP-1 \& -2) productions in MDS and AML myeloid leukemia BM-MNCs and also correlate the variant genotype associated secretion or production of
MMP-2, MMP-9, TIMP-1 and TIMP-2 in myelodysplastic syndrome (MDS) and acute myeloid leukemia (AML) and correlate with disease severity and its susceptibility in Indian population.

\section{Materials and Methods}

A total of 82 (50 MDS \& 32 AML) cases were recruited from the Department of Hematology, King Edward Memorial Hospital, Mumbai, India, after obtaining clearance from Institutional Ethical Committee. Detailed information of each patient was noted in a pretested proforma. The study was approved by institutional ethical committee of the National Institute of Hematology, KEM Hospital, Mumbai, India. $6 \mathrm{ml}$ of blood and bone marrow was collected after taking written consent from all the patients. A detail clinical proforma was filled up for all the patients. The criteria for the diagnosis were based on patient's physical and clinical symptoms. Information regarding the patient's name, age, sex, addiction habits, chemical \& X-ray exposure was gathered. Emphasis was given to addictions such as tobacco chewers (i.e. areca nut chewing with tobacco, Pan and slaked lime), smokers (i.e. cigarette and bidi smokers), and alcohol drinker by the patients. Briefly, individuals who formerly or currently chewed three pouches of tobacco with areca nut and pan/ day, smoked four cigarettes or bidi/day and consumed alcohol $(\sim 300 \mathrm{ml})$ three times/week for at least 5 years were defined as tobacco chewers, smokers and drinkers, respectively. For chemicals exposure person like farmers, chemical making company workers were included, those frequently used different agricultural fertilizers, pesticide since last 5-8 years and X-Ray exposed person more than five times in the life were included in this study.

The complete blood counts (CBCs) were measured on an automated blood cell counter (Sysmex K-1000, America Inc.). 110 normal blood donor comprise as healthy control. The BM squash slides were examined independently by 3 experienced hematologists. If there was any discrepancy, a fourth opinion was obtained to reach a final diagnosis. None of the AML patients gave a history of having MDS prior to developing malignancy.

\section{Isolation of CD34+ mononuclear cells:}

Histopaque-1077 was used for isolation of bone marrow mononuclear cells (BM-MNCs) (Sigma-Aldrich, co. USA). The CD34 MicroBead Kit was used for isolation of CD34+ cells in patients and healthy controls. After purification with Ficoll, one part of the1X 106 BM-MNCs from each individual was directly used for RNA isolation, and another part was washed twice with 1X PBS and cultured $1 \times 106$ cells $/ \mathrm{ml}$ under serum-free conditions in RPMI 1640 (Sigma Chemical Co., Munich, Germany) supplemented with Nutridoma-SP (Boehringer Mannheim GmbH, Mannheim, Germany) in the presence of antibiotics. After $48 \mathrm{hrs}$ cultured, conditioned media were harvested by centrifugation and subsequently stored at $-20^{\circ} \mathrm{C}$ until further use.

Secretion (Zymography analysis) of gelatinases (MMP-2 \& MMP-9) in the culture supernatant of CD34+ bone 
marrow mononuclear cells

Zymography was used for the determination of actually secreted gelatinases-A and B (MMP-2 \& -9) in BM-MNCs in cell culture supernatants as per manufacturer protocol. Novex ${ }^{\circledR}$ Zymogram Gels were used for detecting and characterizing gelatinase such as MMP-2 (gelatinase A, $72 \mathrm{kDa}$ gelatinase, $72 \mathrm{kDa}$ type IV collagenase) \& MMP-9 (matrix metallopeptidase 9 (gelatinase B, 92kDa gelatinase, $92 \mathrm{kDa}$ type IV collagenase) by using gelatin as a substrate (Invitrogen, Grand Island, USA) (Issa et al., 2009).

Measurement (ELISA) of MMP-2, MMP-9, TIMP-1 and TIMP-2 in culture supernatant of CD34+ bone marrow mononuclear cells

CD34+ BM-MNCs cultured supernatant of MMP2, MMP-9, TIMP-1 and TIMP-2 were determined by sandwich ELISA reagent kits obtained from RayBiotech, Inc, GA, USA. Appropriate recombinant human protein was used to establish the standard curve for MMP-2, MMP-9, TIMP-1 and TIMP-2, respectively. The assay was performed according to the manufacturer's protocol. MMP-2, MMP-9, TIMP-1 and TIMP-2 concentration was calculated from each standard curve. The concentrations were calculated after subtraction of the control values. Controls included FCS-supplemented RPMI 1640 medium alone incubated under the same condition.

RNA isolation, cDNA synthesis \& mRNA expression analysis

RiboPure $^{\mathrm{TM}}$ kit (Invitrogen Pvt. Ltd.USA) was used for RNA isolation. $2 \mu \mathrm{g}$ of RNA was reverse transcribed with the High Capacity cDNA Reverse Transcription Kit (Applied Biosystems, USA). RT-PCR were performed using specific FAM-MGB labeled probes for MMP-2 (Hs01548727_m1, Chr.16,), MMP-9 (Hs00234579_m1, Chr.20,), TIMP-2 (Hs00171558_m1, Chr.X 47,), TIMP-2 (Hs00234278_m1,Chr. 17,), and GAPDH (Hs02758991_ $\mathrm{g} 1$, chr. 12,) was used as housekeeping gene. PCR was carried out in a $20 \mu 1$ volume containing $3 \mu \mathrm{l}(30 \mathrm{ng})$ of cDNA template, using standard RT-PCR protocol. The threshold cycle number $(\mathrm{Ct})$ value for each reaction was calculated using the $7900 \mathrm{HT}$ system SDS software.

Genotyping (PCR-RFLP \& DNA direct sequencing) of MMP-2 (-1306 C/T), MMP-9 $(-1562 C / T) \&$ its inhibitors, TIMP-1(372 T/C) and TIMP-2 (-418G/C)

Genomic DNA was extracted from the blood samples by using the Qiagen QIAamp DNA Blood Mini Kit (Qiagen Inc. USA) as per manual instructions and protocol. PCR-RFLP was performed for MMP-2 (-1306 C/T), MMP-9 (-1562 C/T), TIMP-1(372 T/C) and TIMP-2 (-418G/C). Supplementary Table 1 shows the PCR primers used for amplification (Supplementary Table 1). PCR was performed in the total volume of $50 \mu \mathrm{l}$ with $1 \mathrm{U}(0.5 \mu \mathrm{l})$ of Taq DNA polymerase (Fermentas Inc. Glen Burine MD) $5.0 \mu \mathrm{l}$ 10X PCR Buffer, $25 \mathrm{mM} \mathrm{MgCl} 2,10 \mathrm{mM}$ of each dNTPs and 10 pmol of primers, 50-100 ng of genomic DNA. The PCR program used was $5 \mathrm{~min}$ at $95^{\circ} \mathrm{C}$, followed by 35 cycles of $30 \mathrm{sec}$ at $95^{\circ} \mathrm{C}$ and $60.0^{\circ} \mathrm{C}, 60.5^{\circ} \mathrm{C}, 58.5^{\circ} \mathrm{C}$, $61.5^{\circ} \mathrm{C}$ for MMP-2 (-1306C/T), MMP-9 (-1562 C/T),
MP-1 (372T/C), TIMP2 (-418G/C) respectively for 30 sec, $72^{\circ} \mathrm{C}$ for $30 \mathrm{sec}$ and with a final extension at $72^{\circ} \mathrm{C}$ for $5 \mathrm{~min}$. For a negative control, instead of DNA sample, distilled water was used in a PCR reaction mixture.

The PureLink ${ }^{\mathrm{TM}}$ Quick Gel Extraction Kit was used to purify PCR product fragments directly from agarose gels as instructed by manufacturer protocol. The uncharacterized mutations were identified by automated DNA sequencing on the ABI Prism 310 sequencer. The Gene Scan Analysis program on the ABI Prism 310 DNA Sequencer was used for the confirmation of MMP-2 (-1306C/T), MMP-9 (-1562C/T), TIMP-1(372T/C) and TIMP-2 (418G/C) polymorphisms.

\section{Statistical analysis}

The Chi-square test ( $\chi^{2}$ test) was used to analyses the genotype distribution of MMP-2, -9 \& TIMP-1, -2 polymorphisms between the groups. A $p$ value of $<0.05$ was considered as statistically significant. HardyWeinberg equilibrium was tested in the control subjects to rule out sampling bias. The Fischer exact probability test was used for comparing the gelatinases activity. The GraphPad and MedCal software were used for the statistical analysis.

\section{Results}

Of total 82 hematological malignant patients, 50 were myelodysplastic syndrome (MDS), 32 were acute myeloid leukemia (AML). 110 normal healthy individual comprise of control group. MMP-2 (-1306 C/T; rs243865), MMP-9 (-1562 C/T; rs3918242), TIMP-2 (-418 G/C; rs 8179090) promoter polymorphism and TIMP-1 (-372 $\mathrm{T} / \mathrm{C} ; \mathrm{rs} 4898)$ polymorphism were analyzed in patients and controls with respect to age, addiction habits like tobacco chewing, cigarette smoking and alcohol intake along with environmental exposure. The demographic distribution and WHO classification of the patient groups are summarized in Supplementary Table 2.

Secretion of the gelatinase $A$ and $B(M M P-2,-9)$ from CD34+ BM-MNCs of the MDS and AML

Total of 50 MDS patients with RCUD ( $\mathrm{n}=16)$, RAEB-I $(\mathrm{n}=07)$, MDS RAEB-II ( $\mathrm{n}=04)$, RCMD $(\mathrm{n}=18)$, RARS $(n=03)$ and MDS associated with isolated del $(5 q)(n=02)$ were included in the study. The blast percentage reported in MDS and AML patients is summarized in Figure 1 (A) $\&$ (B). We examined secretion of gelatinase A and B in cultured BN-MNCs of MDS, AML and, healthy controls using gelatin zymography. The two major gelatinolytic activities (Gelatin A; MMP-2 (72 Kda) and Gelatin B; MMP-9 (92Kda) were reported (Figure 1C \& D).

MMP-9 was found to be expressed in BM-MNCs conditioned media of all cases of healthy controls, while expression of MMP-2 was found to be lower in healthy controls. In contrast MMP-9 expression showed strong secretion in MDS-RAEB II and RCMD with high blast it might be due to increased blast percentage of the MDS patients (Figure 1 C). MMP-2 was not shown any significant association with progression of MDS according to the WHO classification. In AML patient, secretion of 
Ajay K Chaudhary et al

Table 1. Genotypic distribution of MMP-2 (-1306 C/T; rs243865), MMP-9 (-1562 C/T; rs3918242) TIMP-1 (-372 T/C; rs4898, Exon 5) and TIMP-2 (-418 G/C; rs8179090) polymorphism in control, MDS and AML cases. *p-value is calculated by using Fisher Exact Probability Test via control vs MDS \& control vs AML

\begin{tabular}{|c|c|c|c|c|c|c|c|c|}
\hline \multicolumn{2}{|c|}{ MMP-2 (-1306 C/T) } & $\mathrm{C} / \mathrm{C}$ & $\mathrm{C} / \mathrm{T}$ & $\mathrm{T} / \mathrm{T}$ & $\begin{array}{c}\mathrm{T} \text { allele } \\
\text { frequency }\end{array}$ & $*$ p-value & OR & $95 \% \mathrm{CI}$ \\
\hline \multicolumn{2}{|c|}{ CONTROL (n=110) } & $88(80.0 \%)$ & $20(18.2 \%)$ & $02(1.8 \%)$ & 0.1 & - & 1 & referent \\
\hline \multirow{2}{*}{ CASES(n=108) } & MDS (50) & $40(80.0 \%)$ & $09(18.0 \%)$ & $01(2.0 \%)$ & 0.11 & 0.98 & 1.01 & $0.47-2.15$ \\
\hline & AML (32) & $20(62.5 \%)$ & $10(31.3 \%)$ & $02(6.3 \%)$ & 0.22 & $<0.035$ & 2.28 & $1.10-4.73$ \\
\hline \multicolumn{2}{|c|}{ MMP-9 (-1562 C/T) } & $\mathrm{C} / \mathrm{C}$ & $\mathrm{C} / \mathrm{T}$ & $\mathrm{T} / \mathrm{T}$ & $\begin{array}{c}\mathrm{T} \text { allele } \\
\text { frequency }\end{array}$ & *p-value & OR & $95 \% \mathrm{CI}$ \\
\hline \multicolumn{2}{|c|}{ CONTROL $(\mathrm{n}=110)$} & $62(56.4 \%)$ & $44(40.0 \%)$ & $04(3.6 \%)$ & 0.24 & - & 1 & referent \\
\hline \multirow{2}{*}{ CASES $(n=108)$} & MDS (50) & $22(44.0 \%)$ & $20(40.0 \%)$ & $08(16.0 \%)$ & 0.36 & $<0.022$ & 1.72 & $1.08-3.03$ \\
\hline & AML (32) & $11(34.4 \%)$ & $18(56.3 \%)$ & $03(9.3 \%)$ & 0.37 & $<0.029$ & 1.94 & $1.07-3.51$ \\
\hline \multicolumn{2}{|l|}{ TIMP-1 (372T/C) } & $\mathrm{T} / \mathrm{T}$ & $\mathrm{C} / \mathrm{T}$ & $\mathrm{C} / \mathrm{C}$ & $\begin{array}{c}\mathrm{C} \text { allele } \\
\text { frequency }\end{array}$ & $*$ p-value & OR & $95 \% \mathrm{CI}$ \\
\hline \multicolumn{2}{|c|}{ CONTROL $(n=110)$} & $28(25.4 \%)$ & $72(65.5 \%)$ & $10(9.1 \%)$ & 0.58 & - & 1 & referent \\
\hline \multirow[b]{2}{*}{ CASES (n=108) } & $\operatorname{MDS}(50)$ & $19(38 \%)$ & $30(60 \%)$ & $01(2 \%)$ & 0.68 & 0.09 & 0.65 & $0.39-1.07$ \\
\hline & AML (32) & $12(37.5 \%)$ & $\begin{array}{c}18 \\
(56.25 \%) \\
\end{array}$ & $02(6.25 \%)$ & 0.71 & 0.38 & 1.25 & $0.75-2.10$ \\
\hline \multicolumn{2}{|l|}{ TIMP2 (-418G/C) } & $\mathrm{G} / \mathrm{G}$ & $\mathrm{G} / \mathrm{C}$ & $\mathrm{C} / \mathrm{C}$ & $\begin{array}{c}\mathrm{G} \text { allele } \\
\text { frequency }\end{array}$ & $*$ p-value & OR & $95 \% \mathrm{CI}$ \\
\hline \multicolumn{2}{|c|}{ CONTROL (n=110) } & $\begin{array}{c}82 \\
(74.54 \%) \\
\end{array}$ & $23(20.9 \%)$ & $05(4.54 \%)$ & 0.89 & - & 1 & referent \\
\hline \multirow[b]{2}{*}{ CASES $(n=108)$} & MDS (50) & $31(62 \%)$ & $18(36 \%)$ & $01(2 \%)$ & 0.8 & 0.2 & 1.4 & $0.808-2.75$ \\
\hline & AML (32) & $20(62.5 \%)$ & $\begin{array}{c}10 \\
(31.25 \%) \\
\end{array}$ & $02(6.25 \%)$ & 0.78 & 0.14 & 1.6 & $0.831-3.35$ \\
\hline
\end{tabular}

Supplimentary Table 1. Single nucleotide polymorphic (SNP) sites, rs ID, forward and reverse primer (FP and RP) sequences, annealing temperature (Ta), detection method, restriction enzyme (RE), and annealing temp

\begin{tabular}{|c|c|c|c|c|c|}
\hline Gene; SNPs & rs ID & Primer sequences (forward and reverse primers) & $\begin{array}{l}\text { Restriction } \\
\text { Enzyme }\end{array}$ & $\begin{array}{l}\text { Annealing } \\
\text { temp }\left({ }^{\circ} \mathrm{C}\right)\end{array}$ & $\begin{array}{l}\text { Method of } \\
\text { Detection }\end{array}$ \\
\hline \multirow{2}{*}{$\begin{array}{l}\text { MMP-2 } \\
(-1306 \mathrm{C} / \mathrm{T})\end{array}$} & \multirow{2}{*}{ rs 243865} & 5'-CTTCCTAGGCTGGTCCTTACTGA-3', & \multirow{2}{*}{ BseDI } & \multirow{2}{*}{$60.0^{\circ} \mathrm{C}$} & RFLP\& \\
\hline & & 5'-CTGAGACCTGAAGAGCTAAAGAGCT-3' & & & Sequencing \\
\hline \multirow{2}{*}{$\begin{array}{l}\text { MMP-9 } \\
(-1562 \mathrm{C} / \mathrm{T})\end{array}$} & \multirow{2}{*}{ rs3918242 } & 5'-GCCTGGCACATAGTAGGCCC-3', & \multirow{2}{*}{ SphI } & \multirow{2}{*}{$60.5^{\circ} \mathrm{C}$} & RFLP\& \\
\hline & & 5'-CTTCCTAGCCAGCCGGCATC-3' & & & Sequencing \\
\hline \multirow{2}{*}{$\begin{array}{l}\text { TIMP-1 } \\
(372 \mathrm{~T} / \mathrm{C})\end{array}$} & rs4898, & \multirow{2}{*}{$\begin{array}{l}\text { 5'-GCACATCACTACCTGCAGTCT-3' } \\
\text { 5'-GAAACAAGCCCACGATTTAG-3' }\end{array}$} & \multirow{2}{*}{ BssSI } & \multirow{2}{*}{$58.8^{\circ} \mathrm{C}$} & RFLP\& \\
\hline & Exon 5 & & & & Sequencing \\
\hline \multirow{2}{*}{$\begin{array}{l}\text { TIMP2 } \\
(-418 \mathrm{G} / \mathrm{C})\end{array}$} & \multirow{2}{*}{ rs8179090 } & FP: 5'- CGT CTC TTG TTG GCT GGT CA-3' & \multirow{2}{*}{ Bso BI } & \multirow{2}{*}{$61.5^{\circ} \mathrm{C}$} & RFLP\& \\
\hline & & RP: 5'-CCT TCA GCT CGA CTC TGG AG-3' & & & Sequencing \\
\hline
\end{tabular}

MMP-9 was found to be increase in AML M-1 \&M-4 (approx. 60-70 \% blast) as compared to healthy controls (Figure $1 \mathrm{D}$ ). Hence these result indicates that increase blast percentage participates in the over expression of MMP-9 as compared to normal MNCs in in-vitro condition.

Relative quantification of the $m R N A$ expression of MMP2, MMP-9 and its inhibitors, TIMP-1 \& TIMP-2 in MDS and $A M L$

The mRNA expression levels of MMP-2 did not show much difference among the MDS patients and healthy control groups while in case of MMP-9 mRNA level showed approximately 2.0 fold increased expression in RAEB-II as compared to healthy controls. While in cases of RCMD and del(5q), MMP-9 is also showed 1.5 fold elevated mRNA expression. In this study, higher level of MMP-9 mRNA expression were found in excessive blast cases and it indicate that increase level of MMP-9 mRNA expression were more towards the higher grade of MDS patients (Figure $1 \mathrm{E}$ ). In case of AML, MMP-2 mRNA expression was slightly elevated in all groups of AML cases, while in case of MMP-9 mRNA expression it showed 2.5 fold increased expression in AML M-4 cases. In case of del (5q) in MDS, also represent 1.5 fold increased expression in MDS patients. TIMP-1 and TIMP2 mRNA expression levels showed reduce level among MDS and AML patients (Figure $1 \mathrm{~F}$ ). These result supports the gelatinolytic activity results from cultured supernatant of the MNCs in in-vitro condition

Quantification of secretions of MMP-2, MMP-9, TIMP-1 \& TIMP-2 from BM-MNCs of the MDS and AML

The quantification of MMP-2, MMP-9, TIMP-1 
Table 2. (A) Genotypic distribution of MMP-2 (-1306 C/T; rs243865) and MMP-9 (-1562 C/T; rs3918242) among MDS cases according to the WHO classification. For MMP-2 (-1306 C/T) p value is calculated via Fisher's exact Probability test; control vs RCMD: $\mathrm{p}=0.9$ (NS), 95\% CI=0.33-3.13, OR=1.02 and for MMP-9 (-1562 C/T) p value; control vs *RAEB-II: p<0.024, 95\% CI=1.24-23.29, OR=5.38. NS: Not significant. (B) Genotypic distribution of MMP-2 (-1306 C/T; rs243865), and MMP-9 (-1562 C/T; rs3918242) polymorphism in AML cases, according to the WHO classification. For MMP-2 (-1306 C/T) p value is calculated via Fisher's exact Probability test; control vs *M4: $\mathbf{p}<0.001,95 \% \mathrm{CI}=1.95-19.15, \mathrm{OR}=6.1$ and for MMP-9 $(-1562 \mathrm{C} / \mathrm{T})$ all AML group showed not significant $p$ value. NS: Not significant.

\begin{tabular}{|c|c|c|c|c|c|c|c|c|c|}
\hline (A) & \multicolumn{5}{|c|}{ MMP-2 (-1306 C/T) } & \multicolumn{4}{|c|}{ MMP-9 (-1562C/T) } \\
\hline \multicolumn{2}{|c|}{ Genotypes } & $\mathrm{C} / \mathrm{C}$ & $\mathrm{C} / \mathrm{T}$ & $\mathrm{T} / \mathrm{T}$ & $* \mathrm{p}$ & $\mathrm{C} / \mathrm{C}$ & $\mathrm{C} / \mathrm{T}$ & $\mathrm{T} / \mathrm{T}$ & $* p$ \\
\hline \multicolumn{2}{|c|}{ CONTROL $(\mathrm{n}=110)$} & $88(80.0 \%)$ & $\begin{array}{c}20 \\
(18.2 \%) \\
\end{array}$ & $\begin{array}{c}02 \\
(1.8 \%) \\
\end{array}$ & - & $\begin{array}{c}62 \\
(56.4 \%) \\
\end{array}$ & $\begin{array}{c}44 \\
(40.0 \%) \\
\end{array}$ & $\begin{array}{c}04 \\
(3.6 \%) \\
\end{array}$ & - \\
\hline \multirow{6}{*}{ MDS $n=50$} & RCUD (n=16) & $\begin{array}{c}13 \\
(81.3 \%)\end{array}$ & $\begin{array}{c}03 \\
(18.7 \%)\end{array}$ & 0 & NS & $\begin{array}{c}08 \\
(50.0 \%)\end{array}$ & $\begin{array}{c}08 \\
(50.0 \%)\end{array}$ & 0 & NS \\
\hline & $\begin{array}{l}\text { MDS RAEB-I } \\
(\mathrm{n}=07)\end{array}$ & $\begin{array}{c}06 \\
(85.7 \%)\end{array}$ & $\begin{array}{c}01 \\
(14.3 \%)\end{array}$ & 0 & NS & $\begin{array}{c}03 \\
(42.9 \%)\end{array}$ & $\begin{array}{c}02 \\
(28.5 \%)\end{array}$ & $\begin{array}{c}02 \\
(28.5 \%)\end{array}$ & NS \\
\hline & $\begin{array}{l}\begin{array}{l}* \text { MDS RAEB-II } \\
(\mathrm{n}=04)\end{array} \\
\end{array}$ & $\begin{array}{c}03 \\
(75.0 \%) \\
\end{array}$ & $\begin{array}{c}01 \\
(25.0 \%) \\
\end{array}$ & 0 & NS & $\begin{array}{c}01 \\
(25.0 \%) \\
\end{array}$ & $\begin{array}{c}01 \\
(25.0 \%) \\
\end{array}$ & $\begin{array}{c}02 \\
(50.0 \%) \\
\end{array}$ & $<0.02$ \\
\hline & *RCMD (n=18) & $\begin{array}{c}15 \\
(83.3 \%) \\
\end{array}$ & $\begin{array}{c}02 \\
(11.1 \%) \\
\end{array}$ & $\begin{array}{c}01 \\
(5.6 \%) \\
\end{array}$ & NS & $\begin{array}{c}08 \\
(44.4 \%) \\
\end{array}$ & $\begin{array}{c}07 \\
(38.9 \%) \\
\end{array}$ & $\begin{array}{c}03 \\
(16.6 \%) \\
\end{array}$ & NS \\
\hline & RARS (n=03) & $\begin{array}{c}02 \\
(66.7 \%) \\
\end{array}$ & $\begin{array}{c}01 \\
(33.3 \%) \\
\end{array}$ & 0 & NS & $\begin{array}{c}01 \\
(33.3 \%) \\
\end{array}$ & $\begin{array}{c}01 \\
(33.3 \%) \\
\end{array}$ & $\begin{array}{c}01 \\
(33.3 \%) \\
\end{array}$ & NS \\
\hline & $\begin{array}{l}\text { MDS associated } \\
\text { with isolated del } \\
(5 q)(n=02)\end{array}$ & $\begin{array}{c}01 \\
(50.0 \%)\end{array}$ & $\begin{array}{c}01 \\
(50.0 \%)\end{array}$ & 0 & NS & $\begin{array}{c}01 \\
(50.0 \%)\end{array}$ & $\begin{array}{c}01 \\
(50.0 \%)\end{array}$ & 0 & NS \\
\hline (B) & \multicolumn{5}{|c|}{ MMP-2 (-1306 C/T) } & \multicolumn{4}{|c|}{ MMP-9 (-1562C/T) } \\
\hline \multicolumn{2}{|c|}{ Genotypes } & $\mathrm{C} / \mathrm{C}$ & $\mathrm{C} / \mathrm{T}$ & $\mathrm{T} / \mathrm{T}$ & $\mathrm{P}^{*}$ & $\mathrm{C} / \mathrm{C}$ & $\mathrm{C} / \mathrm{T}$ & $\mathrm{T} / \mathrm{T}$ & $\mathrm{P}^{*}$ \\
\hline \multicolumn{2}{|c|}{ CONTROL $(\mathrm{n}=110)$} & $\begin{array}{c}88 \\
(80.0 \%)\end{array}$ & $\begin{array}{c}20 \\
(18.2 \%)\end{array}$ & $\begin{array}{c}02 \\
(1.8 \%)\end{array}$ & - & $\begin{array}{c}62 \\
(56.4 \%)\end{array}$ & $\begin{array}{c}44 \\
(40.0 \%)\end{array}$ & $\begin{array}{c}04 \\
(3.6 \%)\end{array}$ & - \\
\hline \multirow{5}{*}{$\operatorname{AML} n=32$} & M0 $(n=02)$ & $\begin{array}{c}01 \\
(50.0 \%) \\
\end{array}$ & $\begin{array}{c}01 \\
(50.0 \%) \\
\end{array}$ & 0 & NS & $\begin{array}{c}01 \\
(50.0 \%) \\
\end{array}$ & $\begin{array}{c}01 \\
(50.0 \%) \\
\end{array}$ & 0 & NS \\
\hline & M1 (n=06) & $\begin{array}{c}05 \\
(83.3 \%) \\
\end{array}$ & $\begin{array}{c}01 \\
(16.7 \%) \\
\end{array}$ & 0 & NS & $\begin{array}{c}02 \\
(33.3 \%) \\
\end{array}$ & $\begin{array}{c}04 \\
(66.7 \%) \\
\end{array}$ & 0 & NS \\
\hline & M2 $(n=12)$ & $\begin{array}{c}09 \\
(75.0 \%) \\
\end{array}$ & $\begin{array}{c}02 \\
(16.7 \%) \\
\end{array}$ & $\begin{array}{c}01 \\
(8.3 \%) \\
\end{array}$ & NS & $\begin{array}{c}05 \\
(41.7 \%)\end{array}$ & $06(50 \%)$ & $\begin{array}{c}01 \\
(8.3 \%)\end{array}$ & NS \\
\hline & M3 (n=05) & $\begin{array}{c}03 \\
(60.0 \%) \\
\end{array}$ & $\begin{array}{c}02 \\
(40.0 \%) \\
\end{array}$ & 0 & NS & $\begin{array}{c}01 \\
(20.0 \%) \\
\end{array}$ & $\begin{array}{c}03 \\
(60.0 \%) \\
\end{array}$ & $\begin{array}{c}01 \\
(20.0 \%)\end{array}$ & NS \\
\hline & $*$ M4 (n=07) & $\begin{array}{c}02 \\
(28.6 \%) \\
\end{array}$ & $\begin{array}{c}04 \\
(57.1 \%) \\
\end{array}$ & $\begin{array}{c}01 \\
(14.3 \%) \\
\end{array}$ & $<0.001$ & $\begin{array}{c}02 \\
(28.6 \%) \\
\end{array}$ & $\begin{array}{c}04 \\
(57.1 \%) \\
\end{array}$ & $\begin{array}{c}01 \\
(14.3 \%) \\
\end{array}$ & NS \\
\hline
\end{tabular}

and TIMP-2 levels in BM-MNCs cultured supernatant were also determined using sandwich ELISA. The mean MMP-9 level in MDS-RAEB-II was significantly higher as compared to the controls $(\mathrm{P}<0.04)$. Similarly levels of TIMP-1 and TIMP-2 were also found to be higher in MDSRAEB-I and RAEB-II. Among the AML patients mean MMP-9 levels was also were found to be significantly higher $(\mathrm{p}<0.048)$ in AML-M4 than that of healthy controls, while in case of our study we were also found more secretion level of MMP-2 and its inhibitors level in cultured supernatant of the bone marrow mononuclear in MDS and AML as compared to healthy controls (Supplementary table 3).

MMP-9 (-1562 C/T) polymorphic variant genotype (T/T) associated with $m R N A$ expression level in MDS and AML

We were correlate the mRNA expression of all the genotype of MMP-2, MMP-9, TIMP-1 and TIMP-2 in MDS, AML and controls group, to show the whether these polymorphism have any association with increase expression at mRNA level. We were found the relative MMP-9 mRNA expression of $\mathrm{C} / \mathrm{T}$ and $\mathrm{T} / \mathrm{T}$ genotype have $1.5 \& 1.8$ fold increased level respectively, as compared to healthy controls, while in case of relative MMP-2, TIMP-1 \& TIMP-2 mRNA were not showed any association with these genotype in MDS cases (Figure 2 A, B, C \& D). In cases of AML, relative MMP-9 mRNA expression of $\mathrm{C} / \mathrm{C}$ genotype have 1.5 fold $\& \mathrm{~T} / \mathrm{T}$ genotype have approximately 2.5 fold increased level as compared to healthy controls while in case of relative MMP-2 mRNA expression of $\mathrm{C} / \mathrm{T}$ and $\mathrm{T} / \mathrm{T}$ genotype showed approximately 2.0 fold increased mRNA expression but TIMP-1 \& TIMP-2 mRNA were not showed any association with these genotype (Figure 2 E F G \&H).

Genotypic distributions of MMP-2 (-1306 C/; rs243865T) MMP-9(-1562C/T; rs3918242), TIMP-1 (372T/C; rs4898) and TIMP-2 (-418 G/C; rs8179090) polymorphism in $M D S$ and $A M L$ cases

In the case of MMP-2 (-1306 C/T) genotypic 


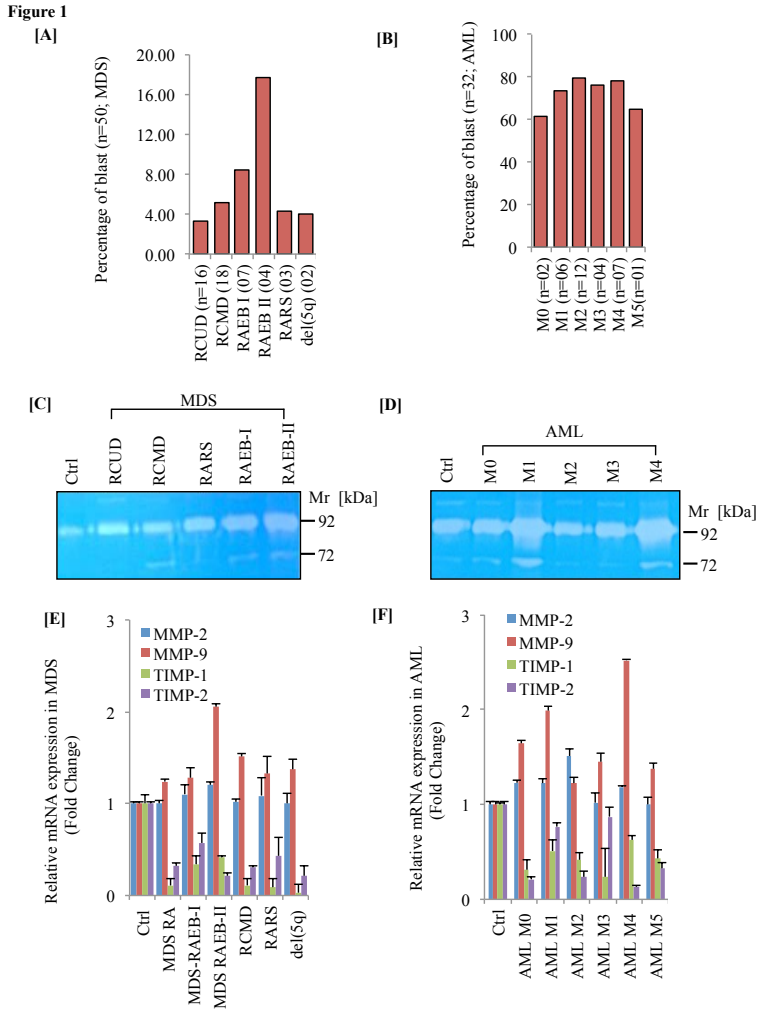

Figure 1. Zymographic Analysis of Gelatinolytic Activities of MMP-2 (Gelatinase-A) and MMP-9 (Gelatinase-B), Released and mRNA Expression of MMP-2, -9, TIMP-1, and TIMP-2 from Cultured Supernatant Of Ex-Vivo Bm-Mncs. Zymogram (A) shown representative selection of MDS patients according to WHO classification (RCUD, RCMD, RARS, RAEB-I \& RAEB-II), and (B) AML with FAB classification (M0, M1, M2, M3 \& M4). CD34+ BM-MNCs were purified from BM aspirates and cultivated up to $48 \mathrm{hrs}$ under serum-free conditions. Novex precast zymogram (gelatin) gels represented as light areas,which indicated zones of gelatinolytic activity of Mr $72 \mathrm{kDa}$ of MMP-2 (type IV collagenase)(C), and $92 \mathrm{kDa}$ represented as MMP-9 (type IV collagenase) (D). Comparative analysis of relative mRNA expression (Fold change) of MMP-2, MMP-9, TIMP1 and TIMP-1 were analyzed using $2 \mu \mathrm{g}$ of RNA to convert cDNA of the myelodysplastic syndrome (E), and acute myeloid leukemia $(\mathrm{F})$. The threshold cycle number $(\mathrm{Ct})$ value for each reaction was calculated using the $7900 \mathrm{HT}$ system SDS software

distribution in MDS, AML and controls were analyzed through polymerase chain reaction restriction fragment length polymorphism (PCR-RFLP) and direct DNA sequencing for the confirmation of polymorphism. The frequency of variant ' $\mathrm{T}$ ' allele did not show significant MMP-2 (-1306 C/T) promoter polymorphic association in case of MDS ( $\mathrm{T}$ allele frequency $=0.11, \mathrm{p}=0.98$ ), while in AML cases, MMP-2 (-1306 C/T) genotypic distribution of variant ' $\mathrm{T}$ ' allele frequency showed significant association ( $\mathrm{T}$ allele frequency $=0.22, \mathrm{p}<0.035)$ as compared to healthy controls. In case of MMP-9 (-1562C/T) genotypic distribution in these hematological cases, the frequency of variant ' $T$ ' allele showed significant association in case of MDS (T allele frequency 0.36, $\mathrm{p}<0.022$ ) and AML cases ( $T$ allele frequency $0.37, \mathrm{p}<0.029$ ) as compared to healthy controls (Table 1). PCR-RFLP \& chromatogram showed
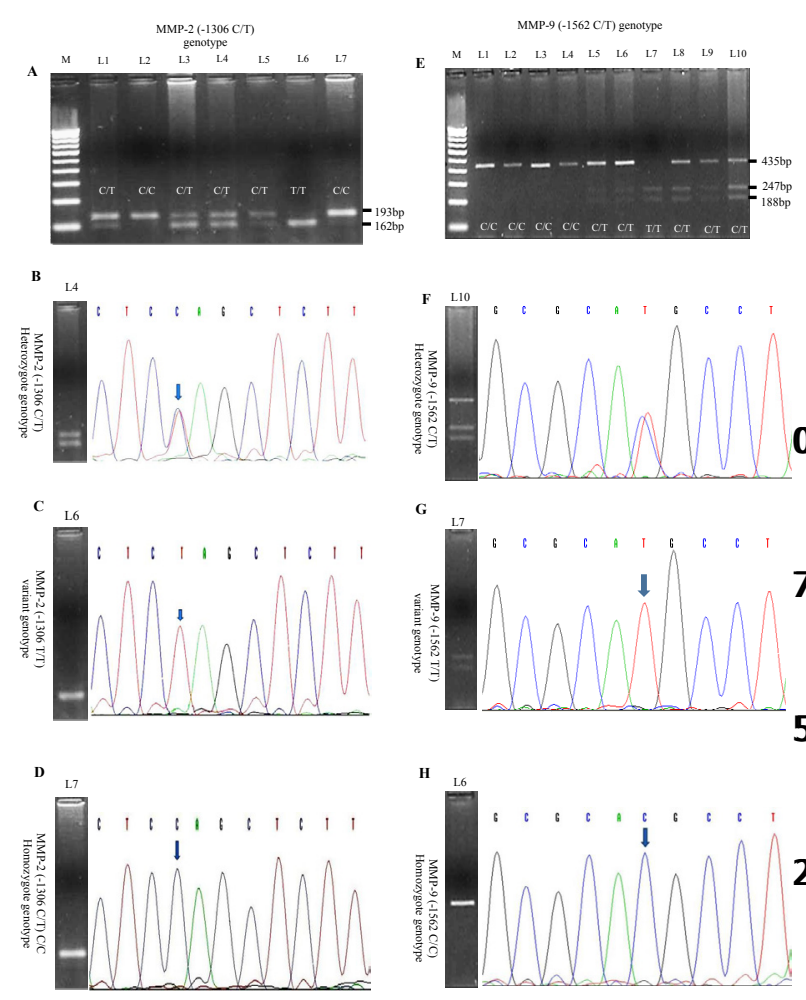

Figure 2. MMP-2 (-1306 C/T rs243865), and MMP9 (-1562 C/T, rs3918242) promoter polymorphisms were analyzed via PCR-RFLP analysis and further, electropherogram of the DNA direct sequencing showing confirmation of promoter polymorphism. Gel picture represent the ' $M$ ': 100 bp molecular weight markers, L2 \&L7: C/C genotype; L1, L3, L4, L5: C/T genotype; and L6: T/T genotype. (A) Electropherogram peak showed DNA direct sequencing of MMP-2 (-1306C/T) heterozygote genotype (B), variant genotype (C), and homozygote genotype (D). Gel picture of MMP-9 (-1562 C/T, rs3918242) promoter polymorphism, represented as ' $\mathrm{M}$ ': 100 bp molecular weight markers, L1, L2, L3 \&L4: C/C genotype; L5, L6, L8, L9\& L10: C/T genotype; and L7: T/T genotype (E). Electropherogram peak showed DNA direct sequencing of MMP-9 (-1562 C/T) heterozygote genotype (F), variant genotype (G) and, homozygote genotype $(\mathrm{H})$

confirmation of all alleles in cases of MMP-2 (-1306C/T) (Figure 2 A, B, C \& D) and MMP-9 (-1562C/T) (Figure 2 E, F, G \& H) promoter polymorphism. TIMP-1 (372T/C) \& TIMP-2 (-418G/C) were not showed any significant association with MDS \& AML (Table 1).

Genotypic distribution of MMP-2 (-1306 C/T) and MMP$9(-1562 \mathrm{C} / \mathrm{T})$ in $M D S \&$ cases according to the WHO classification

According to the WHO classification of MDS, genotypic distribution of MMP-2 (-1306C/T) promoter polymorphism in RCUD, refractive anemia with excessive blast -I (RAEB-I), refractive anemia with excessive blastII (RAEB-II) and refractive cytopenia with multilineage dysplasia (RCMD) does not showed any significant association. While in case of genotypic distribution of MMP-9 $(-1562 \mathrm{C} / \mathrm{T})$ promoter polymorphism with RAEB-II $(\mathrm{p}<0.02)$ have significant association (Table 2 A). In AML-M4 cases, those patients having acute 
Table 3. Genotypic distribution of MMP-2 (-1306 C/T; rs243865), and MMP-9 (-1562 C/T; rs3918242) polymorphism in MDS and AML cases, according to the addiction habits and environmental exposure. In case of MDS and AML ; MMP-2 (-1306 C/T) \& MMP-9 (-1562 C/T), p value is calculated via Fisher's exact Probability test; control chemicals and $\mathrm{X}$-ray exposed person vs diseased chemicals and $\mathrm{X}$-ray exposed person, vs Tobacco chewer + cigarette smokers, vs Alcohol addiction. NS: Not significant

\begin{tabular}{|c|c|c|c|c|c|c|c|c|}
\hline \multicolumn{5}{|c|}{ MMP-2 (-1306 C/T) genotype } & \multicolumn{4}{|c|}{ MMP-9 (-1562 C/T) genotype } \\
\hline Characteristics & CONTROL $(\mathrm{n}=110)$ & MDS $(n=50)$ & OR & $\begin{array}{c}\mathrm{p} \\
\text { value }\end{array}$ & $\begin{array}{c}\text { CONTROL } \\
(\mathrm{N}=110)\end{array}$ & $\begin{array}{c}\text { MDS cases } \\
(\mathrm{n}=50)\end{array}$ & OR & $\mathrm{p}$ value \\
\hline \multicolumn{9}{|c|}{ Chemicals \& X-Ray Exposed person } \\
\hline $\mathrm{C} / \mathrm{C}+\mathrm{C} / \mathrm{T}$ & $44 / 45(97.7 \%)$ & $21 / 22(95.5 \%)$ & 2.2 & NS & $43 / 45(95.6 \%)$ & $06 / 12(50.0 \%)$ & 4 & $<0.001$ \\
\hline $\mathrm{T} / \mathrm{T}$ & $01 / 45(2.2 \%)$ & $01 / 22(4.5 \%)$ & & & $02 / 45(4.4 \%)$ & $06 / 12(50.0 \%)$ & & \\
\hline \multicolumn{9}{|c|}{ Tobacco Chewer+ Cigarette Smokers } \\
\hline $\mathrm{C} / \mathrm{C}+\mathrm{C} / \mathrm{T}$ & $39 / 40(97.5 \%)$ & $12 / 12(100 \%)$ & 1.05 & NS & $39 / 40(97.5 \%)$ & $21 / 22(95.5 \%)$ & 1.8 & NS \\
\hline $\mathrm{T} / \mathrm{T}$ & $01 / 40(2.5 \%)$ & $00 / 12(0.0 \%)$ & & & $01 / 40(2.5 \%)$ & $01 / 22(4.5 \%)$ & & \\
\hline \multicolumn{9}{|c|}{ Alcohol addiction } \\
\hline $\mathrm{C} / \mathrm{C}+\mathrm{C} / \mathrm{T}$ & $25 / 25(100 \%)$ & $16 / 16(100 \%)$ & 1.5 & NS & $24 / 25(96.0 \%)$ & $15 / 16(93.7 \%)$ & 1.6 & NS \\
\hline $\mathrm{T} / \mathrm{T}$ & $00 / 25(0.0 \%)$ & $00 / 16(0.0 \%)$ & & & $01 / 25(04.0 \%)$ & $01 / 16(6.25 \%)$ & & \\
\hline \multicolumn{5}{|c|}{ MMP-2 (-1306 C/T) genotype } & \multicolumn{4}{|c|}{ MMP-9 $(-1562 \mathrm{C} / \mathrm{T})$ genotype } \\
\hline Characteristics & CONTROL $(\mathrm{N}=110)$ & $\operatorname{AML}(\mathrm{n}=32)$ & OR & $\begin{array}{c}\mathrm{p} \\
\text { value }\end{array}$ & $\begin{array}{c}\text { CONTROL } \\
(\mathrm{N}=110)\end{array}$ & $\operatorname{AML}(\mathrm{n}=32)$ & OR & $\mathrm{p}$ value \\
\hline \multicolumn{9}{|c|}{ Chemicals \& X-Ray Exposed person } \\
\hline $\mathrm{C} / \mathrm{C}+\mathrm{C} / \mathrm{T}$ & $44 / 45(97.7 \%)$ & $09 / 10(90 \%)$ & 4.8 & NS & $43 / 45(95.6 \%)$ & $09 / 10(90 \%)$ & 1.3 & NS \\
\hline $\mathrm{T} / \mathrm{T}$ & $01 / 45(2.2 \%)$ & $01 / 10(10 \%)$ & & & $02 / 45(4.4 \%)$ & $01 / 10(10 \%)$ & & \\
\hline \multicolumn{9}{|c|}{ Tobacco Chewer+ Cigarette Smokers } \\
\hline $\mathrm{C} / \mathrm{C}+\mathrm{C} / \mathrm{T}$ & $39 / 40(97.5 \%)$ & $07 / 8(87.5 \%)$ & 5.5 & NS & $39 / 40(97.5 \%)$ & $06 / 8(75 \%)$ & 3 & $<0.04$ \\
\hline $\mathrm{T} / \mathrm{T}$ & $01 / 40(2.5 \%)$ & $01 / 8(12.5 \%)$ & & & $01 / 40(2.5 \%)$ & $02 / 8(25 \%)$ & & \\
\hline \multicolumn{9}{|c|}{ Alcohol addiction } \\
\hline $\mathrm{C} / \mathrm{C}+\mathrm{C} / \mathrm{T}$ & $25 / 25(100.0 \%)$ & $13 / 14(92.8 \%)$ & 5.6 & NS & $24 / 25(96.0 \%)$ & $13 / 14(92.8 \%)$ & 1.86 & NS \\
\hline $\mathrm{T} / \mathrm{T}$ & $00 / 25(0.0 \%)$ & $01 / 14(7.2 \%)$ & & & $01 / 25(04.0 \%)$ & $01 / 14(7.2 \%)$ & & \\
\hline
\end{tabular}

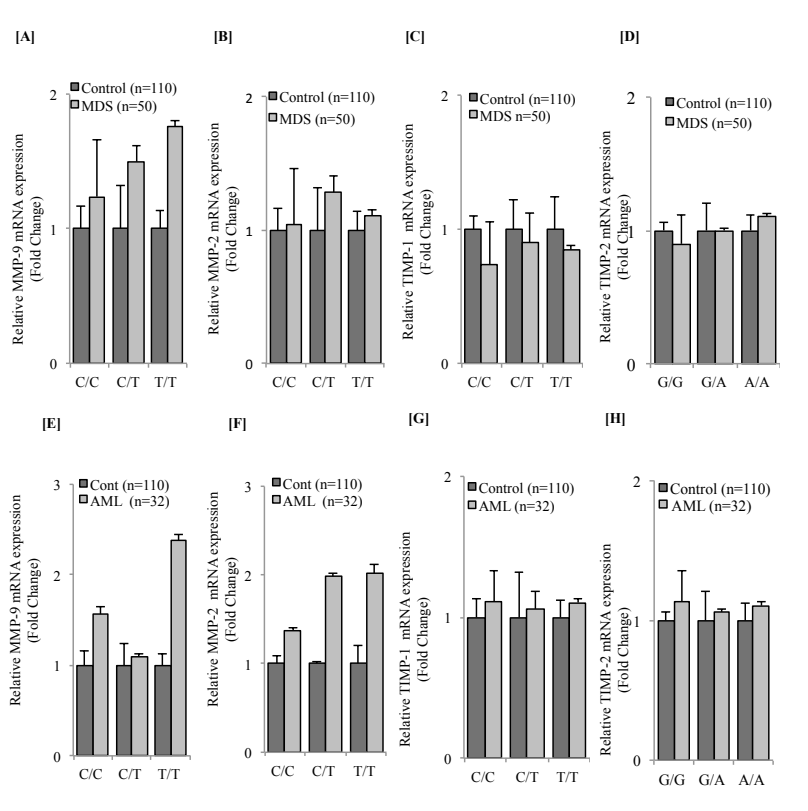

Figure 3. Comparative Analysis Showed Relative mRNA Expression (fold changes) of MMP-2, MMP9, TIMP-1 and TIMP-1 Genotype in MDS and, AML. (A) MMP-9 (B)MMP-2 (C) TIMP-1 (D) TIMP-2 represented as mRNA expression vs genotype of MDS cases vs control and in AML cases, (E) MMP-9 (F)MMP-2 (G) TIMP-1 (H) TIMP-2represented as mRNA expression vs genotype of AML cases $v s$ control mylomonocytic leukemia showed significant polymorphic association in MMP-2 (-1306C/T) promoter polymorphism $(\mathrm{p}<0.001)$. While in MMP-9 $(-1562 \mathrm{C} / \mathrm{T})$ promoter polymorphism do not showed any significant association as compared to healthy individuals (Table $2 \mathrm{~B}$ ).

Genotypic distribution of MMP-2 (-1306 C/T) and MMP-9 (-1562 C/T) gene in MDS, AML, ALL and CML cases with relation to various addiction habits and environmental exposure

The association between MMP-2 (-1306 C/T) and MMP-9 (-1562 C/T) genotypes in the MDS, AML, and control groups with various addiction habits \& environmental exposures are shown in Tables 3 . In the MDS group, MMP-2 (-1306C/T) genotype does not showed association in relation with induced chemicals like different agricultural fertilizers, pesticide, and X-Ray exposed person more than five times in the life. But in case of MMP-9 (-1306 C/T), these different agricultural fertilizers, pesticide, and X-Ray exposed person showed high significant association $(\mathrm{p}<0.001)$. Therefore, that person exposed with these kind of exposure, have 4 fold increased susceptibility towards the myelodysplastic syndrome. In the AML case of the MMP-9 (-1562 $\mathrm{C} / \mathrm{T})$ polymorphism have a significant 13 fold $(\mathrm{p}<0.04)$ increased risk in case of tobacco chewer and cigarette smokers exposed person, while in case of MMP-2 (-1306 
Ajay $K$ Chaudhary et al

Supplimentary Table 3. Detection of MMP-2, MMP-9, TIMP-1 and TIMP-2 levels in the cultured supernatant of 1 X106 cells of MDS and AML patients. All concentrations were calculated after subtraction of the control values. [Detection range of MMP-2, MMP-9, TIMP-1 and TIMP-2 were $3.5 \mathrm{ng} / \mathrm{ml}-800 \mathrm{ng} / \mathrm{ml}, 10 \mathrm{pg} / \mathrm{ml}-6000 \mathrm{pg} /$ $\mathrm{ml}, 2 \mathrm{pg}-1200 \mathrm{pg} / \mathrm{ml}, 25 \mathrm{pg} / \mathrm{ml}-7000 \mathrm{pg} / \mathrm{ml}$ respectively, given in the kit). In Control group, average secretion level of MMP-2, MMP-9, TMIP-1 \& TIMP-2 were $48.46( \pm 3.54)$ ng/ml, $1101.65( \pm 932.72)$ pg/ml, $126.73( \pm 4.23)$ $\mathrm{pg} / \mathrm{ml}, 1276.24( \pm 2.73) \mathrm{pg} / \mathrm{ml}]$

\begin{tabular}{|c|c|c|c|c|}
\hline Hematological Parameters & $\begin{array}{c}\text { MMP-2 }(\mathrm{ng} / \mathrm{ml}) \\
\text { Avg. }( \pm \text { SD) }\end{array}$ & $\begin{array}{c}\text { MMP-9 }(\mathrm{pg} / \mathrm{ml}) \\
\text { Avg. }( \pm \text { SD) }\end{array}$ & $\begin{array}{l}\text { TIMP-1 (pg/ml) } \\
\text { Avg. }( \pm \text { SD) }\end{array}$ & $\begin{array}{c}\text { TIMP-2 (pg/ml) } \\
\text { Avg. }( \pm \text { SD) }\end{array}$ \\
\hline \multicolumn{5}{|l|}{$\operatorname{MDS}(n=50)$} \\
\hline RCUD (n=16) & $52.45( \pm 4.76)$ & $160.65( \pm 5.4)$ & $68.43( \pm 3.76)$ & $162( \pm 4.32)$ \\
\hline $\operatorname{RCMD}(n=18)$ & $61.47( \pm 3.21)$ & $255.21( \pm 7.6)$ & $82.87( \pm 4.21)$ & $253.65( \pm 3.8)$ \\
\hline MDS RAEB-I $(\mathrm{n}=07)$ & $110.45( \pm 8.1)$ & $287.45( \pm 3.02)$ & $97.34( \pm 3.23)$ & $621.29( \pm 3.21)$ \\
\hline MDS RAEB-II (n=04) & $106.23( \pm 12.5)$ & $372.65( \pm 5.72)$ & $139.61( \pm 4.93)$ & $543.98( \pm 4.5)$ \\
\hline RARS (n=03) & $85.43( \pm 6.23)$ & $140.29( \pm 3.12)$ & $103.76( \pm 3.31)$ & $565.82( \pm 2.5)$ \\
\hline MDS associated with isolated del $(5 \mathrm{q})(\mathrm{n}=02)$ & $98.23( \pm 2.65)$ & $208.34( \pm 2.43)$ & $72.54( \pm 4.86)$ & $221.87( \pm 4.6)$ \\
\hline \multicolumn{5}{|l|}{$\operatorname{AML}(\mathrm{n}=32)$} \\
\hline M0 $(n=02)$ & $50.65( \pm 4.21)$ & $232.57( \pm 8.9)$ & $42.43( \pm 5.32)$ & $143.98( \pm 3.65)$ \\
\hline M1 $(n=06)$ & $69( \pm 2.93)$ & $298.67( \pm 6.5)$ & $50.92( \pm 2.43)$ & $376.28( \pm 2.54)$ \\
\hline M2 $(n=12)$ & $87.65( \pm 4.57)$ & $332.56( \pm 9.2)$ & $62.86( \pm 3.98)$ & $219.42( \pm 3.29)$ \\
\hline M3 $(n=04)$ & $123.82( \pm 4.32)$ & $445.87( \pm 10.2)$ & $186.34( \pm 4.96)$ & $451.98( \pm 4.5)$ \\
\hline M4 $(n=07)$ & $110.43( \pm 4.5)$ & $590.54( \pm 7.5)$ & $62.93( \pm 2.54)$ & $105.25( \pm 4.76)$ \\
\hline M5 $(n=01)$ & $109.62( \pm 4.12)$ & $381.64( \pm 7.3)$ & $81.46( \pm 3.65)$ & $118.78( \pm 5.34)$ \\
\hline
\end{tabular}

Supplimentary Table 2. Demographic distribution and clinical parameters of the Myelodysplastic Syndrome (MDS) and Acute Myeloid leukemia (AML) patients. RCUD=refractive cytopenia with unileniage dysplasia, $\mathrm{RCMD}=$ refractive cytopenia with multileniage dysplasia, RAEB-I=refractive anemia with excessive blast-I, RAEB-II: refractive anemia with excessive blast-II, RARS= refractive anemia with ring sideroblast, del5 (q): MDS associated with isolated del (5q)

\begin{tabular}{|l|l|c|}
\hline \multicolumn{1}{|c|}{$\begin{array}{c}\text { Demographic distribution \& clinical } \\
\text { parameters }\end{array}$} & Age; mean $( \pm$ SD) \\
\hline \multirow{5}{*}{ MDS (n=50) } & MDS subtype: & \\
\cline { 2 - 3 } & RCUD $(\mathrm{n}=16)$ & $50.18( \pm 11.95)$ \\
\cline { 2 - 3 } & RCMD $(\mathrm{n}=18)$ & $63.67(13.65 \pm)$ \\
\cline { 2 - 3 } & MDS RAEB-I $(\mathrm{n}=07)$ & $55.72( \pm 12.38)$ \\
\cline { 2 - 3 } & MDS RAEB-II $(\mathrm{n}=04)$ & $51.85( \pm 11.24)$ \\
\cline { 2 - 3 } & RARS (n=03) & $55( \pm 6.2)$ \\
\cline { 2 - 3 } & $\begin{array}{l}\text { MDS associated } \\
\text { with isolated del }(5 \mathrm{q}) \\
(\mathrm{n}=02)\end{array}$ & $59.5( \pm 7.77)$ \\
\hline \multirow{5}{*}{ AML (n=32) } & AML subtypes: & $30( \pm 9.19)$ \\
\cline { 2 - 3 } & M0 (n=02) & $44( \pm 9.60)$ \\
\cline { 2 - 3 } & M1 (n=06) & $37( \pm 10.81)$ \\
\cline { 2 - 3 } & M2 (n=12) & $42( \pm 5.48)$ \\
\cline { 2 - 3 } & M3 (n=04) & $41( \pm 11.41)$ \\
\cline { 2 - 3 } & M4 (n=07) & $51(\mathrm{NA})$ \\
\cline { 2 - 3 } & M5 (n=01) & \\
\hline
\end{tabular}

C/T) polymorphism do not showed any significant increased disease risk as compared to healthy individuals (Table 3).

\section{Discussion}

Myelodysplastic syndromes (MDS) are characterized by ineffective hematopoiesis presenting with peripheral cytopenias in combination with a hyperplastic bone marrow and an increased risk of evolution to acute myeloid leukemia (AML) (Ries et al., 1999). Development and progression of MDS is suggested to be a multistep alteration to hematopoietic stem cells. Different molecular alterations have been described, affecting genes involved in cell-cycle control, mitotic checkpoints and growth factor receptors (Schnerch et al., 2012). The accumulation of such defects may finally cause the leukemic transformation of MDS towards the acute myeloid leukemia (AML). This raise the question whether, gelatinases participates in the progression of disease \& can it be used as useful surrogate marker for monitoring the disease. Investigations of gelatinase secretion may open a new area regarding diagnostic and therapeutic However, due to the heterogeneity in the cellular composition of the BM-MNC fraction, the hematopoietic cell populations responsible for the production of these enzymes are not clearly known. In this study we tried to analyze the secretion of gelatinase A \& B (MMP-2 \&-9) in human in-vitro bone marrow cells and also tried to look at its association with MMP-2 \&-9 genotype in MDS and AML cases during the disease progression.

Our results showed that in MDS-RAEB-II patients having $18.5 \%$ blast in the bone marrow, MMP-9 level were significantly higher in cultured supernatant .Similar results were obtained for MMP-2 in MDS and AML and MMP9 in AML-M4 \& TIMP-1 in AML M3 (Supplementary table 3).Thus this data suggests levels of gelatinase was increased towards the progression of disease. Lin et al reported that MMP-9 can be used as a potential marker to assess the leukemic level in AML, while in ALL patients, they found MMP-2 level were higher as compared to BM donors (Lin et al., 2002). Our study also suggests that 
MMP-9 can be used as surrogate marker.

Earlier many study showed that the MMP-9 \&MMP-2 secreted by blast cells provides evidence that it contribute to leukaemic dissemination (Ries et al., 1999). Bcrabl-positive cells secrete angiogenic factors such as VEGF, FGF-2, HGF and IL-8 including MMPs and stimulate angiogenesis and it could play an important role in the pathogenesis of CML (Janowska-Wieczorek et al., 2002). The study of Travaglino et al among MDS patients, showed higher levels of MMP-2 than in controls, while in our study, MMP-2 levels were not much higher as compared to normal bone marrow donor, it could be possible that the production and release of these enzymes may influence haematopoietic cell behavior. The Travaglino et al concluded that in MDS MMP deregulated expression may be useful tool for diagnosis, prognosis and a possible target for experimental treatments (Travaglino et al., 2008).

It is well known that MMP-9 is a major secretory product of macrophages, lymphocytes, keratinocytes, granulocytes\& stromal cells (Yu and Stamenkovic, 2000). To study the role of MMP-9 in the marrow microenvironment, Heissig et al used MMP-9 knockout model and MMP inhibitor, reported a significant role of MMP-9 in the marrow microenvironment (Heissig et al., 2002). In our study, deletion at long arm of the chromosome number 5 (del5q) patients released more MMP-9, this suggests that chromosomal abnormality may also affect the release or secretion of MMPs. (Barille et al., 1997). In our study according to WHO classification of MDS, RAEB-II patients showed increased MMP-9 mRNA expression (2.5 fold) compared to healthy BM donor. Interestingly, del (5q) also have 1.5 fold increase mRNA expression level of MMP-9 (Figure $1 \mathrm{E}$ ). Therefore, MMP9 could be one of the early predictor of the malfunctions of the hematopoiesis.

After the evaluation of the gelatinase and its inhibitors activity, participation in the mRNA and secretion level of the MDS and AML cases, we hypothesized that the whether genetic polymorphism, addiction habits and environmental exposure effect the mRNA level of disease patients as compared to healthy controls. Therefore, we analyzed the polymorphic association of MMP-2 (-1306C/ T), MMP-9 (-1562C/T), TIMP-1 (372T/C) and TIMP-2 $(-418 \mathrm{G} / \mathrm{C})$ in 110 healthy controls including $50 \mathrm{MDS}$ and 32 AML cases. Further, we analyzed the mRNA levels of all the genotypic association in these cases.

Matrix-metalloproteases (MMPs) and their tissueinhibitors (TIMPs), modulated by different single nucleotide polymorphisms (SNPs), are critical in leukemia development. In this study, the frequency of variant ' $\mathrm{T}$ ' allele of MMP-2 (-1306 C/T) promoter polymorphism did not show significant association in MDS $(\mathrm{p}=0.98)$, while in AML cases, it showed significant association $(\mathrm{p}<0.035)$ as compared to healthy controls. Therefore, our study showed positive correlation of MMP-2 (-1306 C/T) in AML cases, not in MDS (Table 1). Recently Gouda et al studied promoter polymorphism of MMP-2 $(-735 \mathrm{C} / \mathrm{T}$ rs243865 and -1306 rs243865) in Non-Hodgkin's lymphomas (NHLs), and reported that the frequency of the polymorphic variant was $5 \%$ for the heteromutant genotype (CT) and 3\% for the homomutant genotype (TT) in case of MMP-2 (-1306C/T)polymorphism in B-NHL patients and MMP-2 (735C/T) polymorphic genotypes was correlated with advanced clinical stages of the disease (stages III \& IV). Finally, they concluded that it revealed the variant alleles of MMP2 $-735 \mathrm{C} / \mathrm{T}$ and $-1306 \mathrm{C} / \mathrm{T}$ can be considered as molecular risk factors for B-NHL among Egyptians (Gouda et al., 2014) whereas in our study, MMP-2 (-1306C/T) don't have any association with MDS, while in case of acute myeloid leukemia it showed significant association (Table 1). According to the WHO classification of MDS, RAEB-II cases showed significant association with MMP-9 (-1562C/T) promoter polymorphism $(\mathrm{p}<0.02)$ but not with MMP-2 $(-1306 \mathrm{C} / \mathrm{T})$, this suggests that MMP-9 $(-1562 \mathrm{C} / \mathrm{T})$ polymorphism may be participating in the progression of disease from lower grade of myeloid to the higher grade (Table 2A). When we tried to correlation mRNA level with genotypes, in MDS patients we found relative MMP-9 mRNA expression of $\mathrm{C} / \mathrm{T}$ and $\mathrm{T} / \mathrm{T}$ genotypes showed 1.5 and 1.8 fold increased levels, Whereas MMP-2,TIMP-1 \& TIMP-2 Did not show any association with genotypes with mRNA expression. (Figure $2 \mathrm{~A}-\mathrm{D})$. In AML-, those patients having M4 acute mylomonocytic leukemia condition showed significant $(\mathrm{p}=0.001)$ polymorphic association in MMP-2 $(-1306 \mathrm{C} / \mathrm{T})$ promoter polymorphism as compared to healthy controls. While in MMP-9 (-1562C/T) promoter polymorphism did not have any association (Table $2 \mathrm{~B}$ ). These results are in concordant with the study of Gouda et al among B-NHL patients (Gouda et al., 2014). Diao et al reported that $\mathrm{T}$ of allele were MMP-2 (-1306C/T) polymorphism was significantly lower in patients with a large tumor size as compared to a smaller tumor (Diao et al., 2012). It has been previously demonstrated that MMP-2 plays a critical role in promoting tumor angiogenesis and progression; thus, decreased expression is potentially related to a reduced cancer risk in solid malignancies. Chaudhary et al reported that ' $\mathrm{T}$ ' allele of MMP-2 (-1306 C/T) and MMP-9 (-1562 C/T) promoter polymorphism showed a significant association with the increasing progression of head and neck squamous cell carcinoma(HNSCC) $\&$ concluded that these polymorphism may participate in the progression of disease from premalignant to malignant stages of the tumor in head and neck lesions (Chaudhary et al., 2011). Apart from production \& release of these gelatinases, it participated in the progression of disease from non-aggressive to aggressive stages of hematological malignancies. Therefore, MMP-2 \& MMP-9 polymorphisms have significant association in the disease progression. It is confirm from the comparative analysis of the mRNA with different genotype of the MMPs in hematological malignancies.

In the case MDS patients MMP-9 (-1306 C/T) polymorphism showed a significant 4 fold $(\mathrm{p}<0.001)$ increased risk in those patients who were exposure to chemicals \& X-Ray, while inMMP-2 (-1306C/T) genotype did not show any association with exposure and addiction habits. In case of AML tobacco chewer and cigarette smokers have 3 times more increased susceptibility towards the acute myeloid leukemia. Similar results were reported by Chang et al in the oral submucous fibrosis 
(OSMF) patients (Chang et al., 2002) and Lin et al in the cases of oral squamous cell carcinoma (OSCC) (Lin et al., 2004). Chaudhary et al have reported that addiction habits such as areca nut chewing and alcohol abuse may enhance the expression of the $2 \mathrm{G}$ allele of MMP- 1 genes in OSMF and HNSCC cases (Chaudhary et al., 2010a). On the other hand, Vairaktaris et al reported that $\mathrm{T}$ allele carriers have an increased risk for developing oral cancer only in initial stages, but not in advanced one, and it may be due to the role of MMP-9 in the inhibition of angiogenesis by generating angiostatin from plasminogen (Vairaktaris et al., 2008). While no study was available in addiction and environmental factor associated polymorphic analysis of MMP-2 and MMP-9 in hematological disorders. This study shows polymorphic association of MMP-9 (-1562C/ $\mathrm{T})$ allele with addiction habits and environmental exposure and suggests that it might have participated in the initiation of progression of hematological malignancies. In view of our results, concluded that MMP-9 plays synergistic polymorphic effect of secretion and expression in MDS \& AML BM-MNCs and significantly associated with increased risk with tobacco, cigarette and, environmental exposure.

This work provides the first evidence for the polymorphic association of gelatinases (MMP-2 \& -9) mRNA expression in both leukemic development (MDS and AML). We suggest evaluation of larger number patients in order to establish definite correlations between MMPs SNPs and mRNA level with respect to the clinical features of hematological malignancies. This might enable us to determine the importance of these enzymes as a molecular marker tool and for formulating new drug target therapies. Furthermore, the specific role of these gelatinases in normal and malignant haemopoiesis requires more clarification. In addition, questions regarding the regulation of MMPs and TIMPs production in the haemopoietic microenvironment by various growth factors, cytokines, ECM and adhesion molecules need to be addressed with respect to more number of polymorphic association as well as expression analysis.

In conclusions, In view of our results, MMP-9 plays synergistic secretion and expression in blast crises of MDS and AML with polymorphic effect and significantly associated with increased risk with tobacco, cigarette and, environmental exposure. The release and secretion of these enzymes may influence hematopoietic cell behavior and may be important in the clinical point of view. It may deliver valuable tool for diagnosis, prognosis and possible target for the treatments.

\section{Acknowledgements}

The authors thank the Indian Council of Medical Research (ICMR), Ministry of Health and Family Welfare, New Delhi, for providing financial support for post-doctoral work (Grant No. 3/1/3/PDF-4/HRD$2011 / 4$ th batch) to AKC for this study. Authors are also thankful to persistent efforts of an enthusiastic group of Department of Hematogenetic staff for their participation in the present study.

\section{References}

Barille S, Akhoundi C, Collette M, et al (1997). Metalloproteinases in multiple myeloma: production of matrix metalloproteinase-9 (MMP-9), activation of proMMP-2, and induction of MMP-1 by myeloma cells. Blood, 90, 1649-55.

Chang YC, Yang SF, Tai KW, et al (2002). Increased tissue inhibitor of metalloproteinase-1 expression and inhibition of gelatinase A activity in buccal mucosal fibroblasts by arecoline as possible mechanisms for oral submucous fibrosis. Oral Oncol, 38, 195-200.

Chaubey R, Sazawal S, Dada R, et al (2011). Cytogenetic profile of Indian patients with de novo myelodysplastic syndromes. Indian J Med Res, 134, 452-7.

Chaudhary AK, Pandya S, Ghosh K, et al (2013). Matrix metalloproteinase and its drug targets therapy in solid and hematological malignancies: an overview. Mutat Res, $\mathbf{7 5 3 ,}$ $7-23$.

Chaudhary AK, Pandya S, Mehrotra R, et al (2010a). Functional polymorphism of the MMP-1 promoter $(-16071 \mathrm{G} / 2 \mathrm{G})$ in potentially malignant and malignant head and neck lesions in an Indian population. Biomarkers, 15, 684-92.

Chaudhary AK, Pandya S, Mehrotra R, et al (2011). Role of functional polymorphism of matrix metalloproteinase-2 $(-1306 \mathrm{C} / \mathrm{T}$ and $-168 \mathrm{G} / \mathrm{T})$ and MMP-9 (-1562 C/T) promoter in oral submucous fibrosis and head and neck squamous cell carcinoma in an Indian population. Biomarkers, 16, 577-86.

Chaudhary AK, Singh M, Bharti AC, et al (2010b). Genetic polymorphisms of matrix metalloproteinases and their inhibitors in potentially malignant and malignant lesions of the head and neck. J Biomed Sci, 17, 10.

Dakshinamurthy AG, Novitzky N, Bharadwaj R, et al (2005). Cytogenetic analysis of 52 Indian patients with de novo myelodysplastic syndromes-a comparative analysis of results with reports from Asia. Ann Hematol, 84, 298-303.

de Souza Fernandez T, Ornellas MH, Otero de Carvalho L, et al (2000). Chromosomal alterations associated with evolution from myelodysplastic syndrome to acute myeloid leukemia. Leuk Res, 24, 839-48.

Diao LP, Ma H, Wei GC, et al (2012). Matrix metalloproteinase-2 promoter and tissue inhibitor of metalloproteinase- 2 gene polymorphisms in non-Hodgkin's lymphoma. Int J Cancer, 131, 1095-103.

Egeblad M, Werb Z (2002). New functions for the matrix metalloproteinases in cancer progression. Nat Rev Cancer, 2, 161-74.

Galm O, Suzuki H, Akiyama Y, et al (2005). Inactivation of the tissue inhibitor of metalloproteinases-2 gene by promoter hypermethylation in lymphoid malignancies. Oncogene, 24, 4799-805.

Gao H, Peng C, Liang B, et al (2014). beta6 integrin induces the expression of metalloproteinase-3 and metalloproteinase-9 in colon cancer cells via ERK-ETS1 pathway. Cancer Lett, 354, 427-37.

Gouda HM, Khorshied MM, El Sissy MH, et al (2014). Association between matrix metalloproteinase 2 (MMP2) promoter polymorphisms and the susceptibility to nonHodgkin's lymphoma in Egyptians. Ann Hematol, 93, 1313-8.

Heissig B, Hattori K, Dias S, et al (2002). Recruitment of stem and progenitor cells from the bone marrow niche requires MMP-9 mediated release of kit-ligand. Cell, 109, 625-37.

Hwang TL, Changchien TT, Wang CC, et al (2014). Claudin-4 expression in gastric cancer cells enhances the invasion and is associated with the increased level of matrix metalloproteinase-2 and -9 expression. Oncol Lett, 8, 
1367-71.

Ishihara M, Nishida C, Tashiro Y, et al (2012). Plasmin inhibitor reduces $\mathrm{T}$-cell lymphoid tumor growth by suppressing matrix metalloproteinase-9-dependent CD11b(+)/F4/80(+) myeloid cell recruitment. Leukemia, 26, 332-9.

Issa A, Le TX, Shoushtari AN, et al (2009). Vascular endothelial growth factor-C and C-C chemokine receptor 7 in tumor celllymphatic cross-talk promote invasive phenotype. Cancer Res, 69, 349-57.

Issa JP (2013). The myelodysplastic syndrome as a prototypical epigenetic disease. Blood, 121, 3811-7.

Janowska-Wieczorek A, Majka M, Marquez-Curtis L, et al (2002). Bcr-abl-positive cells secrete angiogenic factors including matrix metalloproteinases and stimulate angiogenesis in vivo in Matrigel implants. Leukemia, 16, 1160-6.

Kalluri R (2003). Basement membranes: structure, assembly and role in tumour angiogenesis. Nat Rev Cancer, 3, 422-33.

Klepin HD, Rao AV, Pardee TS (2014). Acute myeloid leukemia and myelodysplastic syndromes in older adults. J Clin Oncol.

Kossakowska AE, Edwards DR, Prusinkiewicz C, et al (1999). Interleukin- 6 regulation of matrix metalloproteinase (MMP2 and MMP-9) and tissue inhibitor of metalloproteinase (TIMP-1) expression in malignant non-Hodgkin's lymphomas. Blood, 94, 2080-9.

Langers AM, Verspaget HW, Hawinkels LJ, et al (2012). MMP-2 and MMP-9 in normal mucosa are independently associated with outcome of colorectal cancer patients. Br J Cancer, 106, 1495-8.

Lin LI, Lin DT, Chang CJ, et al (2002). Marrow matrix metalloproteinases (MMPs) and tissue inhibitors of MMP in acute leukaemia: potential role of MMP-9 as a surrogate marker to monitor leukaemic status in patients with acute myelogenous leukaemia. Br J Haematol, 117, 835-41.

Lin SC, Chung MY, Huang JW, et al (2004). Correlation between functional genotypes in the matrix metalloproteinases-1 promoter and risk of oral squamous cell carcinomas. J Oral Pathol Med, 33, 323-6.

Marquez-Curtis LA, Dobrowsky A, Montano J, et al (2001). Matrix metalloproteinase and tissue inhibitors of metalloproteinase secretion by haematopoietic and stromal precursors and their production in normal and leukaemic long-term marrow cultures. Br J Haematol, 115, 595-604.

Ogawa M, Kawamoto M, Yamanaka N (2000). Matrix metalloproteinase and tissue inhibitor of metalloproteinase in human bone marrow tissues-an immunohistochemical study. J Nippon Med Sch, 67, 235-41.

Redondo-Munoz J, Ugarte-Berzal E, Terol MJ, et al (2010). Matrix metalloproteinase-9 promotes chronic lymphocytic leukemia $\mathrm{b}$ cell survival through its hemopexin domain. Cancer Cell, 17, 160-72.

Ries C, Loher F, Zang C, et al (1999). Matrix metalloproteinase production by bone marrow mononuclear cells from normal individuals and patients with acute and chronic myeloid leukemia or myelodysplastic syndromes. Clin Cancer Res, 5, 1115-24.

Rollison DE, Howlader N, Smith MT, et al (2008). Epidemiology of myelodysplastic syndromes and chronic myeloproliferative disorders in the United States, 2001-2004, using data from the NAACCR and SEER programs. Blood, 112, 45-52.

Roy R, Zurakowski D, Wischhusen J, et al (2014). Urinary TIMP-1 and MMP-2 levels detect the presence of pancreatic malignancies. Br J Cancer, 111, 1772-9.

S VANN, Skarstedt M, Lofgren S, et al (2013). Gene polymorphism of matrix metalloproteinase- 12 and -13 and association with colorectal cancer in Swedish patients. Anticancer Res, 33, 3247-50. disruption of normal hematopoiesis. Cell, 64, 337-50.

Schnerch D, Yalcintepe J, Schmidts A, et al (2012). Cell cycle control in acute myeloid leukemia. Am J Cancer Res, 2 , 508-28.

Stetler-Stevenson M, Mansoor A, Lim M, et al (1997). Expression of matrix metalloproteinases and tissue inhibitors of metalloproteinases in reactive and neoplastic lymphoid cells. Blood, 89, 1708-15.

Travaglino E, Benatti C, Malcovati L, et al (2008). Biological and clinical relevance of matrix metalloproteinases 2 and 9 in acute myeloid leukaemias and myelodysplastic syndromes. Eur J Haematol, 80, 216-26.

Vairaktaris E, Vassiliou S, Nkenke E, et al (2008). A metalloproteinase- 9 polymorphism which affects its expression is associated with increased risk for oral squamous cell carcinoma. Eur J Surg Oncol, 34, 450-5.

Vundinti BR, Kerketta L, Jijina F, et al (2009). Cytogenetic study of myelodysplastic syndrome from India. Indian $J$ Med Res, 130, 155-9.

Westermarck J, Kahari VM (1999). Regulation of matrix metalloproteinase expression in tumor invasion. FASEB $J$, 13, 781-92.

Yang X, Liu Y, Yang Y, et al (2013). Update meta-analysis on MMP-7 -181A $>$ G polymorphism and cancer risk: evidence from 25 studies. Gene, 521, 252-8.

Yu Q, Stamenkovic I (2000). Cell surface-localized matrix metalloproteinase-9 proteolytically activates TGF-beta and promotes tumor invasion and angiogenesis. Genes Dev, 14, 163-76.

Zhang C, Li C, Zhu M, et al (2013). Meta-analysis of MMP2, MMP3, and MMP9 promoter polymorphisms and head and neck cancer risk. PLoS One, 8, 62023. 